\title{
Evaluating an Action Threshold-Based Insecticide Program on Onion Cultivars Varying in Resistance to Onion Thrips (Thysanoptera: Thripidae)
}

\author{
Brian A. Nault ${ }^{1,2}$ and Anders S. Huseth ${ }^{3}$ \\ ${ }^{1}$ Department of Entomology, Cornell University, New York State Agricultural Experiment Station, 630 W. North St., Geneva, \\ NY 14456 (ban6@cornell.edu), '2Corresponding author, e-mail: ban6@cornell.edu, and ${ }^{3}$ Department of Entomology, Campus Box \\ 7630, North Carolina State University, Raleigh, NC 27695 (ashuseth@ncsu.edu)
}

Received 6 April 2016; Accepted 4 May 2016

\begin{abstract}
Onion thrips, Thrips tabaci Lindeman (Thysanoptera: Thripidae), is a highly destructive pest of onion, Allium cepa L., and its management relies on multiple applications of foliar insecticides. Development of insecticide resistance is common in T. tabaci populations, and new strategies are needed to relax existing levels of insecticide use, but still provide protection against T. tabaci without compromising marketable onion yield. An action threshold-based insecticide program combined with or without a thrips-resistant onion cultivar was investigated as an improved approach for managing T. tabaci infestations in commercial onion fields. Regardless of cultivar type, the average number of insecticide applications needed to manage T. tabaci infestations in the action-threshold based program was 4.3 , while the average number of sprays in the standard weekly program was 7.2 (a $40 \%$ reduction). The mean percent reduction in numbers of applications following the action threshold treatment in the thrips-resistant onion cultivar, 'Advantage', was 46.7\% (range 40-50\%) compared with the standard program, whereas the percentage reduction in applications in action threshold treatments in the thrips-susceptible onion cultivar, 'Santana', was 34.3\% (range 13-50\%) compared with the standard program, suggesting a benefit of the thrips-resistant cultivar. Marketable bulb yields for both 'Advantage' and 'Santana' in the action threshold-based program were nearly identical to those in the standard program, indicating that commercially acceptable bulb yields will be generated with fewer insecticide sprays following an action threshold-based program, saving money, time and benefiting the environment.
\end{abstract}

Key words: Thrips tabaci, host plant resistance, Allium cepa, IPM

Onion thrips, Thrips tabaci Lindeman, is a serious insect pest of onion worldwide (Diaz-Montano et al. 2011, Gill et al. 2015). Thrips tabaci damages onion by feeding on leaves, which results in smaller, less-valuable bulbs (Fournier et al. 1995). Thrips tabaci also transmits economically damaging plant pathogens to onion that cause Iris yellow spot (Gent et al. 2006) and bacterial center rot (Dutta et al. 2014), while its feeding injury can enhance spread and severity of a fungal pathogen that causes purple blotch (McKenzie et al. 1993).

Most onion growers have experienced significant bulb yield and quality reductions from $T$. tabaci damage. Over the past several years in the United States, severe losses in onion bulb yield attributed to T. tabaci have become less common because newer and more effective insecticides have been identified and registered on onion (Nault and Hessney 2006, 2011; Groves et al. 2013). Moreover, new information has been generated to improve T. tabaci management in onion via applying insecticides based on action thresholds for maximum efficacy and efficiency (Nault and Shelton 2010), following specific sequences of insecticide products applied during the season (Byrne and Szendrei 2013, Nault et al. 2014, Reitz 2014), and using surfactants coapplied with insecticides (Nault et al. 2013). Despite these advancements in onion IPM, many growers continue to make insecticide applications on a weekly basis, rather than using action thresholds, because studies are lacking that compare levels of thrips control and marketable bulb yield following the two approaches. Furthermore, T. tabaci is notorious for developing resistance to insecticides (Shelton et al. 2003, 2006), and intensive insecticide use will likely result in resistance to one or several modes of action that would lead to reduced control. Demonstrating the use of an action threshold-based insecticide program for managing T. tabaci is needed to convince onion growers that this approach is effective, reduces insecticide use, and minimizes selection pressure for insecticide resistance.

Future management of $T$. tabaci should consider integrating prudent insecticide use with other tactics, like host plant resistance. Onion germplasm has been evaluated for resistance to T. tabaci in 
the eastern and western United States (Diaz-Montano et al. 2010, Boateng et al. 2014, Cramer et al. 2014). While no highly thripsresistant germplasm sources have been identified, some accessions and cultivars showed either low levels of resistance or tolerance to T. tabaci (Diaz-Montano et al. 2010, Boateng et al. 2014, Cramer et al. 2014). Onions considered more resistant to T. tabaci had leaves that were yellow-green in color with low levels of waxes giving them a glossy to semiglossy appearance. In contrast, T. tabacisusceptible cultivars had leaves that were blue-green with higher levels of waxes (Diaz-Montano et al. 2010, 2012; Cramer et al. 2014). Recently, Damon et al. (2014) concluded that semiglossy onion leaves have intermediate amounts of epicuticular waxes that may protect onions from diseases and environmental stresses, but still conferred resistance to T. tabaci, and that this semiglossy phenotype should be pursued in future thrips management programs.

The purpose of this study was to evaluate management of T. tabaci in onion by combining an action threshold-based insecticide program and an onion cultivar that has thrips resistance. The onion cultivar 'Advantage' (formerly OLYS05N5), which has yellow-green, semiglossy wax leaves, was selected because it ranked among the best cultivars for reducing T. tabaci densities and damage of the 49 entries evaluated in a previous study in New York (DiazMontano et al. 2010), and it also performed well in multiyear field trials in Colorado (Boateng et al. 2014). 'Advantage' matures later than desirable for commercial production in the Great Lakes region of the US; however, 'Advantage' was one of the best choices available for examining the performance of a T. tabaci-management program that combines host plant resistance and judicious insecticide use. We predicted fewer insecticide applications would be needed following an action threshold-based program compared with the standard, weekly insecticide application program, and that fewer applications would be needed to protect 'Advantage' from T. tabaci infestations and damage compared with the thrips-susceptible cultivar 'Santana', which has blue-green, waxy characteristics. Moreover, we predicted that marketable bulb yield would not be compromised following the action threshold-based program compared with the standard application program for either 'Advantage' or 'Santana'.

\section{Materials and Methods}

\section{Study Sites and Onion Cultivars}

Field experiments were conducted in commercial onion fields on muck soil near Elba, NY (USA) from 2012-2014. Onion seeds from 'Advantage' (Crookham Co., Caldwell, ID) and 'Santana' (Bejo Seeds, Inc., Oceano, CA) were planted with a tractor-mounted vacuum seeder on 1 May 2012, 25 April 2013, and 28 April 2014. Both cultivars are described as late-maturing, long-day, yellow onions; 'Advantage' and 'Santana' mature $130 \mathrm{~d}$ and $115 \mathrm{~d}$ after planting, respectively. Onion plots had four rows, each $9.1 \mathrm{~m}$ long, and rows were spaced apart by an average of $38 \mathrm{~cm}$. Plots within and across rows were separated from each other by $1.5 \mathrm{~m}$ and $0.8 \mathrm{~m}$ of bare ground, respectively.

Sites were selected that did not have a history of Iris yellow spot virus and the presence of iris yellow spot symptoms were low to absent during this study. Other plant pathogens and weeds at the study sites were managed following the onion grower's typical management practices. The only other insect pest, Delia antiqua (Meigen), was managed using a commercial seed treatment containing the insecticides spinosad and thiamethoxam (FarMore FI500; Syngenta, Greensboro, NC); residual activity of this product does not extend long enough to impact T. tabaci infestations. Seeds of each cultivar received an identical seed treatment in each year of the study.

\section{Insecticide Treatment Programs and Experimental Design}

Separate experiments were conducted for each onion cultivar because they differed in maturity and yield potential. Cultivars were planted adjacent to each other in the same field in all three years. For each cultivar, a standard program that involved weekly insecticide applications was compared with one based on insecticide applications made following an action threshold. The standard program was initiated for each cultivar when there was an average across all plots of 0.1 to 0.5 larva per leaf. At this time, the average numbers of leaves per 'Advantage' plant were 7, 4, and 9, in 2012, 2013, and 2014, respectively, while for 'Santana' average numbers were 8, 5, and 10, in 2012, 2013, and 2014, respectively. The action threshold program was initiated and then followed during the remainder of the season when there was an average across all plots within a cultivar of $\geq 1$ larva per leaf.

Both insecticide programs included four products with different modes of action and were used in the following sequence during the growing season: 1) spirotetramat (Movento; Bayer CropScience, Research Triangle Park, NC), 2) abamectin (Agri-Mek SC; Syngenta, Greensboro, NC), 3) methomyl (Lannate LV; DuPont Crop Protection, Wilmington, DE), and 4) spinetoram (Radiant SC; Dow AgroSciences, Inc., Indianapolis, IN). The standard program included two applications of each product one week apart. The action threshold-based program followed the same guidelines, but if the thrips infestation did not meet or exceed the action threshold during that week, that product was not applied. Rates of spirotetramat, abamectin, methomyl, and spinetoram used in this study were $0.09 \mathrm{~kg}$ (AI) ha ${ }^{-1}, 0.02 \mathrm{~kg}$ (AI) ha ${ }^{-1}, 1.0 \mathrm{~kg}(\mathrm{AI}) \mathrm{ha}^{-1}$, and $0.05 \mathrm{~kg}$ (AI) $\mathrm{ha}^{-1}$, respectively. For each cultivar, the experimental design included each insecticide treatment program plus an untreated control arranged in an RCBD replicated four times.

\section{Application Technique}

Insecticide applications were made using a $\mathrm{CO}_{2}$-pressurized backpack sprayer equipped with four, twin flat-fan nozzles (TJ-60 8003VS; TeeJet Technologies Harrisburg, PA) that provided uniform spray coverage of the four-row plot. The sprayer was calibrated to deliver between 318 to 337 liters ha ${ }^{-1}$ at $276 \mathrm{kPa}$ over the 3 -yr study. All insecticides were coapplied with a nonionic surfactant (Induce; Helena Chemical Co., Collierville, TN) at $0.5 \%$ vol/ vol to improve efficacy of the insecticides (Nault et al. 2013).

\section{Sampling Thrips and Damage}

Thrips tabaci populations were monitored weekly from early colonization in late June/ early July until onions matured in late August/ early September (=6 to 9 sample dates). Total numbers of thrips larvae were recorded visually from 15 randomly selected plants sampled from the center two rows of each plot. Adults were not recorded because they move between plots; moreover, adults typically comprise a much smaller proportion of the thrips population compared with larvae (Hsu et al. 2010) and larvae typically damage plants more than adults. To determine if the thrips population reached the action threshold, the mean number of thrips larvae per leaf was calculated by taking the mean number of thrips larvae per plant from all plots in that treatment and then dividing by the average number of green leaves per plant, which was determined by randomly sampling 20 plants within each respective cultivar. Thrips 
tabaci voucher specimens are located in the Department of Entomology at the New York State Agricultural Experiment Station in Geneva, NY.

Thrips damage was assessed visually using a 10-point rating scale (Nault and Shelton 2010). A rating of $1=$ no damage; $2=1-10 \%$ of the leaves were white as a consequence of thrips feeding damage; $3=11-20 \%$ damage; $4=21-35 \%$ damage; $5=36-50 \%$ damage; $6=51-65 \%$ damage; $7=66-80 \%$ damage; $8=81-90 \%$ damage; $9=91-99 \%$ damage; and $10=$ complete damage $(100 \%$ leaves white). Thrips damage under $10 \%$ is typically considered commercially acceptable. Visual ratings of thrips damage were made on 27 August 2013 and 3 September 2014. No damage ratings were made in 2012.

\section{Bulb Yield Assessment}

Onion plants from the middle two rows in each plot were harvested on 5, 11, and 18 September in 2012, 2013, and 2014, respectively. Harvested plants were stored in a well-ventilated, screened building to accelerate drying of onion leaves and their eventual separation from bulbs. Bulbs were graded, counted, and weighed on 15 October, 9 October, and 25 September in 2012, 2013, and 2014, respectively. Bulbs were graded into three size classes: jumbo $(\geq 7.6 \mathrm{~cm}$ in diameter), standard $(5.1-7.5 \mathrm{~cm}$ in diameter), or boiler $(3.8-$ $5.0 \mathrm{~cm}$ in diameter). Marketable bulbs were categorized as the sum of jumbo- and standard-sized bulbs. Because there were too few jumbo-sized bulbs in this 3-yr study, no attempt was made to compare bulb size classes among treatments.

\section{Statistical Analyses}

Cumulative numbers of T. tabaci larvae and thrips damage levels late in the season were important criteria for evaluating the efficacy of insecticide programs and the cultivar's resistance to thrips. Mean densities of T. tabaci larvae per leaf per sampling date were calculated by dividing the season total number of larvae per leaf by the total number of sampling dates. Mean number of larvae per leaf per sampling date was the response variable and was analyzed using regression analysis (PROC MIXED, SAS Institute 2012), which considered year and insecticide program as main effects and fixed in the model and replication as a random factor. Data were transformed using a $(\log x+1)$ function to stabilize variance before analysis. Mean thrips damage ratings were analyzed using the same regression model and data also were transformed before analysis using a square root $(x+0.001)$ function. Treatment means were compared using Tukey's Studentized Range [HSD] Test at $P<0.05$ (SAS Institute 2012).

Marketable bulb weight and the percentage of marketable bulbs were additional factors used to evaluate efficacy of the insecticide programs and the cultivar's resistance to thrips. Standardizing bulb yield across plots was important because numbers of onion bulbs differed among plots. This was achieved by calculating the mean marketable weight per bulb (g/ bulb) by dividing total marketable bulb weight per plot by the total number of marketable bulbs per plot. The percentage of marketable bulbs per plot was calculated by dividing the number of marketable bulbs by the total number of all bulbs harvested per plot. Mean marketable weight per bulb and percentage marketable bulbs were response variables and analyzed using the modeling approach described above. Means were compared using LSMEANS at $P<0.05$ (SAS Institute 2012). No transformations were required to stabilize variance in these bulb yield data sets.

\section{Results}

\section{Application Frequencies for Insecticide Programs}

Thrips tabaci infestations exceeded economically damaging levels each year. In 2012 and 2013, the period required to manage T. tabaci in both cultivars spanned eight weeks, while this period was reduced by two to three weeks in 2014 because the study site was not colonized until later in July, presumably a consequence of a cool spring (Table 1).

\section{Advantage}

The standard insecticide program was initiated on 2 July, 3 July, and 29 July in 2012, 2013, and 2014, respectively. The action threshold-based program was initiated about a week later on 10 July 2012 and 8 July 2013, but was the same time as the standard program in 2014. The total number of applications in the action threshold program was reduced by 50, 40, and 50\% compared with the standard program in 2012, 2013, and 2014, respectively (Table 1). In the action threshold program, there was a tendency to skip one to two weeks of insecticide applications following applications of spirotetramat (designated as letter "A" in Table 1).

\section{Santana}

The standard and action threshold-based insecticide programs in the 'Santana' trials were initiated simultaneously on 2 July, 3 July, and 29 July in 2012, 2013, and 2014, respectively. The total number of applications in the action threshold program was reduced by 50,13 , and $40 \%$ compared with the standard program in 2012, 2013, and 2014, respectively (Table 1). As observed in the action threshold program in the 'Advantage' trials, there was a tendency to skip one to two weeks of insecticide applications following applications of spirotetramat (designated as letter "A" in Table 1).

\section{Impact of Insecticide Programs on Season Mean Thrips Densities and Thrips Damage}

Thrips pressure tended to be higher in the thrips-susceptible ('Santana') than in the thrips-resistant cultivar ('Advantage') early in the season (mean number thrips per leaf [ $\pm \mathrm{SE}]$ 'Santana': $9.7 \pm 1.7$, $3.9 \pm 1.4$, and $3.3 \pm 0.5$, in 2012, 2013, and 2014, respectively; mean number thrips per leaf $[ \pm \mathrm{SE}]$ 'Advantage': $6.4 \pm 0.5$, $3.1 \pm 1.0$, and $2.4 \pm 0.2$, in 2012, 2013, and 2014, respectively), but the opposite or similar trend followed later in the season (mean number thrips per leaf [ $\pm \mathrm{SE}$ ] 'Santana': $2.8 \pm 0.6,4.1 \pm 0.8$, and $2.0 \pm 0.5$, in 2012, 2013, and 2014, respectively; mean number thrips per leaf [ \pm SE] 'Advantage': $6.8 \pm 0.4,7.7 \pm 1.0$, and $2.0 \pm 0.4$, in 2012, 2013, and 2014, respectively). This may have been attributed to the later maturity of 'Advantage' compared with 'Santana'.

\section{Advantage}

Thrips tabaci population densities were affected by year, the insecticide program, and an interaction between these two main effects (Table 2). In all years, densities of thrips larvae in the untreated control were significantly greater than those in insecticide-treated plots (Table 3). In 2012, thrips densities in the standard insecticide program were significantly lower than in the action threshold program, but densities were similar between the insecticide treatment programs in the other years (Table 3 ).

Thrips damage was affected by insecticide program, but not by year or by an interaction between year and insecticide program (Table 2). Thrips damage levels in untreated plots were relatively 
Table 1. Insecticides and the dates they were applied to manage onion thrips, T. tabaci, following either a weekly spray schedule (industry standard) or an action threshold-based program (one larva per leaf) on a thrips-resistant ('Advantage') and thrips-susceptible ('Santana') onion cultivar near Elba, NY, from 2012-2014

\begin{tabular}{|c|c|c|c|c|c|c|c|c|c|c|}
\hline \multirow[t]{2}{*}{ Cultivar } & \multirow{2}{*}{$\begin{array}{c}\text { Insecticide } \\
\text { program }\end{array}$} & \multicolumn{8}{|c|}{ Insecticide applications ${ }^{a}$} & \multirow{2}{*}{$\begin{array}{l}\text { Total } \\
\text { sprays }\end{array}$} \\
\hline & & Wk 1 & Wk 2 & Wk 3 & Wk 4 & Wk 5 & Wk 6 & Wk 7 & Wk 8 & \\
\hline 2012 & & 2 July & 10 July & 17 July & 24 July & 2 Aug. & 8 Aug. & 14 Aug. & 20 Aug. & \\
\hline Advantage & Untreated & - & - & - & - & - & - & - & - & 0 \\
\hline Advantage & Weekly & $\mathrm{A}$ & $\mathrm{A}$ & B & B & $\mathrm{C}$ & $\mathrm{C}$ & $\mathrm{D}$ & $\mathrm{D}$ & 8 \\
\hline Advantage & Threshold & - & $\mathrm{A}$ & B & - & - & $\mathrm{C}$ & $\mathrm{D}$ & - & 4 \\
\hline Santana & Untreated & - & - & - & - & - & - & - & - & 0 \\
\hline Santana & Weekly & $\mathrm{A}$ & $\mathrm{A}$ & B & $\mathrm{B}$ & $\mathrm{C}$ & $\mathrm{C}$ & $\mathrm{D}$ & $\mathrm{D}$ & 8 \\
\hline Santana & Threshold & $\mathrm{A}$ & - & - & $\mathrm{B}$ & $\mathrm{C}$ & $\mathrm{C}$ & - & - & 4 \\
\hline 2013 & & 3 July & 8 July & 15 July & 22 July & 29 July & 5 Aug. & 13 Aug. & 19 Aug. & \\
\hline Advantage & Untreated & - & - & - & - & - & - & - & - & 0 \\
\hline Advantage & Weekly & $\mathrm{A}$ & A & B & B & $\mathrm{C}$ & $\mathrm{C}$ & $\mathrm{D}$ & $\mathrm{D}$ & 8 \\
\hline Advantage & Threshold & - & A & - & - & $\mathrm{C}$ & $\mathrm{C}$ & $\mathrm{D}$ & $\mathrm{D}$ & 5 \\
\hline Santana & Untreated & - & - & - & - & - & - & - & - & 0 \\
\hline Santana & Weekly & $\mathrm{A}$ & $\mathrm{A}$ & B & B & $\mathrm{C}$ & $\mathrm{C}$ & $\mathrm{D}$ & $\mathrm{D}$ & 8 \\
\hline Santana & Threshold & $\mathrm{A}$ & $\mathrm{A}$ & - & B & C & C & $\mathrm{D}$ & $\mathrm{D}$ & 7 \\
\hline 2014 & & 29 July & 5 Aug. & 11 Aug. & 18 Aug. & 26 Aug. & 3 Sept. & N/A & N/A & \\
\hline Advantage & Untreated & - & - & - & - & - & - & & & 0 \\
\hline Advantage & Weekly & A & A & $\mathrm{B}$ & B & $\mathrm{D}$ & $\mathrm{D}$ & & & 6 \\
\hline Advantage & Threshold & $\mathrm{A}$ & $\mathrm{A}$ & - & B & - & - & & & 3 \\
\hline Santana & Untreated & - & - & - & - & - & N/A & & & 0 \\
\hline Santana & Weekly & A & A & $\mathrm{B}$ & B & $\mathrm{D}$ & N/A & & & 5 \\
\hline Santana & Threshold & $\mathrm{A}$ & $\mathrm{A}$ & - & B & - & N/A & & & 3 \\
\hline
\end{tabular}

${ }^{a}$ Letters A, B, C, and D refer to the following insecticides: spirotetramat (Movento), abamectin (Agri-Mek SC), methomyl (Lannate LV), and spinetoram (Radiant SC), respectively.

Table 2. Summary statistics (Type 3 tests of fixed effects) for several response variables that were impacted by different insecticide treatment programs used to manage T. tabaci infestations on the thrips-resistant onion cultivar, 'Advantage', and thrips-susceptible onion cultivar, 'Santana', in Elba, NY, from 2012-2014

\begin{tabular}{|c|c|c|c|c|c|c|c|c|c|}
\hline \multirow[t]{2}{*}{ Cultivar } & \multirow[t]{2}{*}{ Source } & \multicolumn{2}{|c|}{$\begin{array}{l}\text { Season mean number } \\
\text { of larvae per leaf }{ }^{a}\end{array}$} & \multicolumn{2}{|c|}{$\begin{array}{l}\text { Visual estimate of } \\
\text { thrips damage }\end{array}$} & \multicolumn{2}{|c|}{$\begin{array}{l}\text { Weight of marketable } \\
\text { yield (g/bulb) }{ }^{a}\end{array}$} & \multicolumn{2}{|c|}{ Percent marketable yield ${ }^{a}$} \\
\hline & & $F$ & $P$ & $F$ & $P$ & $F$ & $P$ & $F$ & $P$ \\
\hline \multirow[t]{3}{*}{ Advantage } & Year & 32.5 & $<0.0001$ & 2.9 & 0.1120 & 29.0 & $<0.0001$ & 8.1 & 0.0021 \\
\hline & Program & 202.4 & $<0.0001$ & 25.2 & $<0.0001$ & 0.7 & 0.5188 & 0.3 & 0.7802 \\
\hline & Year $\times$ Program & 16.4 & $<0.0001$ & 0.9 & 0.4398 & 2.2 & 0.0984 & 1.2 & 0.3491 \\
\hline \multirow[t]{3}{*}{ Santana } & Year & 6.4 & 0.0061 & 1.9 & 0.1907 & 198.0 & $<0.0001$ & 47.0 & $<0.0001$ \\
\hline & Program & 48.2 & $<0.0001$ & 32.3 & $<0.0001$ & 7.6 & 0.0028 & 3.9 & 0.0355 \\
\hline & Year $\times$ Program & 4.0 & 0.0126 & 3.6 & 0.0514 & 1.3 & 0.3134 & 1.7 & 0.1891 \\
\hline
\end{tabular}

\footnotetext{
${ }^{a}$ Numerator and denominator degrees-of-freedom for year and program were 2 and 24, respectively, whereas for the year $\times$ program interaction they were 4 and 24 , respectively.

${ }^{b}$ Numerator and denominator degrees-of-freedom for year and program were 1 and 15 , respectively, whereas for the year $\times$ program interaction they were 2 and 15 , respectively.
}

low $(<17 \%)$, but were significantly greater than those in the insecticide treatment programs; damage levels were similar between the insecticide programs in both years (estimates never exceeded $5 \%$ damage; Table 3).

\section{Santana}

Thrips tabaci larval populations were also affected by year, insecticide program, and an interaction between the two (Table 2). Densities of larvae in the untreated control were significantly greater than those in the insecticide treatment programs (Table 3). As in the 'Advantage' trials, thrips densities in the standard insecticide program in 2012 were significantly lower than those in the action threshold program, but densities were similar between the insecticide treatment programs in the other years (Table 3).
Thrips damage also was affected by insecticide program, but not by year or by an interaction between year and insecticide program (Table 2). Thrips damage levels in the untreated control were moderate to high $(36-60 \%)$ and significantly greater than those in the insecticide treatment programs; damage levels were similar between the insecticide programs in both years and never exceeded $10 \%$, which is the upper limit for being commercially acceptable (Table 3).

\section{Insecticide Program Impact on Marketable Bulb Yield Advantage}

Weight of marketable bulb yield and percentage of marketable bulb yield differed significantly among years of the study (Table 2). Marketable bulb weight and percentage of marketable bulbs in 
Table 3. Season mean larval densities of $T$. tabaci and the feeding damage they caused in onion plantings that received various insecticide treatment programs in thrips-resistant ('Advantage') and thrips-susceptible ('Santana') cultivars near Elba, NY, from 2012-2014

\begin{tabular}{|c|c|c|c|c|}
\hline Year & Cultivar & Insecticide program & $\begin{array}{c}\text { Season mean }( \pm \text { SE }) \text { number } \\
\text { of larvae per leaf }{ }^{a}\end{array}$ & $\begin{array}{l}\text { Mean }( \pm \text { SE) thrips } \\
\text { damage rating }\end{array}$ \\
\hline \multirow[t]{6}{*}{2012} & Advantage & Untreated & $6.6 \pm 0.3 a$ & N/A \\
\hline & Advantage & Weekly & $0.3 \pm 0.1 c$ & N/A \\
\hline & Advantage & Threshold & $1.2 \pm 0.1 b$ & N/A \\
\hline & Santana & Untreated & $6.6 \pm 1.1 \mathrm{a}$ & N/A \\
\hline & Santana & Weekly & $0.6 \pm 0.1 c$ & N/A \\
\hline & Santana & Threshold & $2.4 \pm 0.3 \mathrm{~b}$ & N/A \\
\hline \multirow[t]{6}{*}{2013} & Advantage & Untreated & $5.1 \pm 0.9 \mathrm{a}$ & $16.6 \pm 5.4 \mathrm{a}$ \\
\hline & Advantage & Weekly & $1.2 \pm 0.1 b$ & $3.8 \pm 0.8 b$ \\
\hline & Advantage & Threshold & $1.8 \pm 0.2 b$ & $4.5 \pm 0.0 \mathrm{~b}$ \\
\hline & Santana & Untreated & $4.0 \pm 1.0 \mathrm{a}$ & $59.8 \pm 13.0 \mathrm{a}$ \\
\hline & Santana & Weekly & $1.3 \pm 0.5 b$ & $4.5 \pm 0.0 \mathrm{~b}$ \\
\hline & Santana & Threshold & $1.4 \pm 0.5 b$ & $8.4 \pm 2.5 b$ \\
\hline \multirow[t]{6}{*}{2014} & Advantage & Untreated & $2.2 \pm 0.3 \mathrm{a}$ & $14.6 \pm 2.7 \mathrm{a}$ \\
\hline & Advantage & Weekly & $0.7 \pm 0.1 b$ & $1.4 \pm 0.8 b$ \\
\hline & Advantage & Threshold & $0.7 \pm 0.1 b$ & $3.4 \pm 0.7 b$ \\
\hline & Santana & Untreated & $2.6 \pm 0.2 \mathrm{a}$ & $35.5 \pm 3.1 \mathrm{a}$ \\
\hline & Santana & Weekly & $0.8 \pm 0.1 b$ & $8.6 \pm 2.8 b$ \\
\hline & Santana & Threshold & $0.9 \pm 0.1 b$ & $9.3 \pm 2.4 b$ \\
\hline
\end{tabular}

\footnotetext{
${ }^{a}$ For each year and cultivar combination, means within a column followed by the same letter are not significantly different $(P<0.05$; Tukey's studentized range [HSD] test; $n=4)$.

${ }^{b}$ Damage ratings (scale of $1=$ no damage to $10=100 \%$ damaged) were taken on 27 August 2013 and 3 September 2014; no ratings were taken in 2012.
}

2014 were significantly greater than they were in 2012 and 2013 (Fig. 1A and C). Neither insecticide program nor an interaction between year and insecticide program impacted marketable bulb yield or percentage of marketable bulbs (Table 2; Fig. 1B and D). These results indicated that despite economically damaging densities of T. tabaci larvae and thrips damage levels in the untreated control, marketable yield was not reduced relative to bulb yield from onions protected repeatedly with insecticides. Thus, 'Advantage' tolerated low levels of feeding damage by T. tabaci.

\section{Santana}

Weight of marketable bulb yield and percentage of marketable bulb yield differed significantly among years of the study and varied among insecticide programs (Table 2). Results were similar to those in the 'Advantage' trials, as marketable bulb weight and percentage of marketable bulbs in 2014 were significantly greater than they were in 2012 and 2013 (Fig. 1A and C). Marketable bulb weight and percentage of marketable bulbs in the insecticide treatment programs were significantly greater than those in the untreated control, indicating the importance of protecting a thrips-susceptible cultivar like 'Santana' with insecticides to avoid bulb yield reductions. No bulb yield differences existed between the standard and action threshold-based insecticide programs (Fig. 1B and D).

\section{Discussion}

Thrips tabaci management in onion using action thresholds as guidelines for making insecticide applications has been proposed as an essential step to transition away from calendar-based spray programs (Nault and Shelton 2010). Our results supported the prediction that fewer insecticide applications would be needed to effectively manage T. tabaci infestations in onion following an action threshold-based program compared with a standard, weekly insecticide application program. Across both cultivars, the average number of applications in the action-threshold based program was
4.3, while the average number of sprays in the standard program was 7.2 (a 40\% reduction). These results are nearly identical to those in a previous study in New York in which onion growers averaged 7.6 insecticide applications per season following a weekly insecticide application program, but only 4.8 applications following an action threshold-based program of 1.5 thrips per leaf (a 38\% reduction; Hoffmann et al. 1995).

The combination of action thresholds and highly effective insecticides has had the greatest impact on reducing insecticide use for T. tabaci management in onion (Nault and Shelton 2010). For example, a single application of either formetanate hydrochloride (Carzol SP; Gowan Co., Yuma, AZ) or spinetoram following an action threshold of 1-3 larvae per leaf protected the onion crop for 14-28 d (Nault and Shelton 2010). In our study, a single application of spirotetramat applied following an action threshold of 1 larva per leaf most consistently protected the crop for 14-21 d. The excellent performance of spirotetramat against early-season T. tabaci larval populations is the reason onion growers in the Great Lakes region have been advised to use it at the beginning of a season-long insecticide program (Hoepting 2015, Werling and Szendrei 2015).

We predicted that fewer insecticide applications would be needed to protect 'Advantage' from T. tabaci infestations and damage compared with the thrips-susceptible, 'Santana', and this was true in 2013 and 2014, but no differences existed in 2012. The mean percent reduction in numbers of applications following the action threshold treatment in 'Advantage' trials was 46.7\% (range 40$50 \%$ ) compared with the standard program, whereas the percentage reduction in applications in action threshold treatments in the 'Santana' trials was $34.3 \%$ (range 13-50\%) compared with the standard program, suggesting a benefit of the thrips-resistant cultivar in some years.

Our results also showed that marketable bulb yield would not be compromised following the action threshold-based program compared with the standard application program for either 'Advantage' or 'Santana'. Mean marketable bulb weights and percentages of 

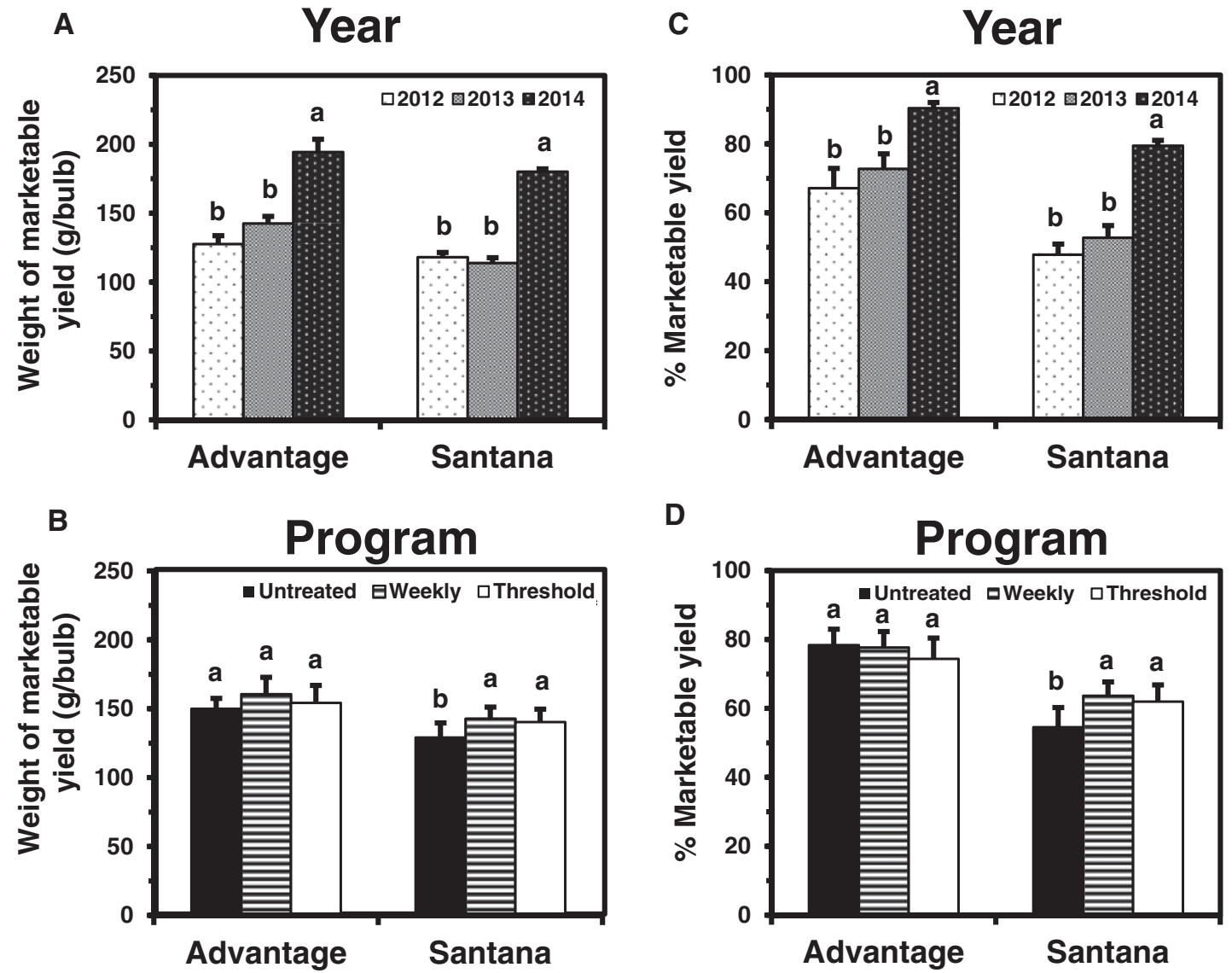

Fig. 1. (A-D) Impact of year and insecticide program main effects on the mean weight of marketable onion bulb yield and percent marketable onion bulb yield in a thrips-resistant ('Advantage') and thrips-susceptible ('Santana') onion cultivar in field studies conducted near Elba, NY, from $2012-2014$.

marketable bulbs in plots treated following the action-threshold based program were nearly identical to those in the standard program. Thus, commercially acceptable bulb yields will be generated with fewer insecticide sprays following an action threshold-based program, saving money, time and benefiting the environment.

'Advantage' has been considered a promising thrips-resistant cultivar (Diaz-Montano et al. 2010, 2012). In a previous study in New York, 'Advantage' ranked among the best onion cultivars having the fewest cumulative numbers of T. tabaci adults and larvae and the least amount of thrips feeding damage among 49 cultivar entries (Diaz-Montano et al. 2010). 'Advantage' had no visual signs of thrips damage in three field studies over two years, whereas the thrips-susceptible 'Santana' had $\sim 13-56 \%$ thrips damage (DiazMontano et al. 2010). In our study, 'Advantage' had higher levels of thrips damage $(15-17 \%)$ than those reported by Diaz-Montano et al. (2010), but thrips damage in 'Santana' was similar (36-60\%). In both years of our study, thrips damage in untreated 'Advantage' plots was significantly greater than thrips damage in insecticidetreated plots, while this was the case in only one of two years in the study by Diaz-Montano et al. (2010). In our study, bulb weights in insecticide-treated 'Advantage' plots were similar to those in untreated plots (Fig. 1B and D), but bulb weights were 31\% lower in unprotected plots compared with those protected from thrips in the Diaz-Montano et al. (2010) study. Unlike results reported by DiazMontano et al. (2010), we found similar cumulative thrips larval densities in untreated plots of 'Advantage' and 'Santana' (Table 3), but thrips damage was much higher in 'Santana' than in 'Advantage'. These results suggest that 'Advantage' is not highly resistant against thrips larvae, but appears sufficient to prevent economically damaging levels of feeding damage by adults and larvae. Our results agree with Diaz-Montano et al.'s (2012) conclusion that 'Advantage' has moderate levels of antibiosis and antixenosis.

Long-term and sustainable management of T. tabaci in onion should consider a combination of multiple tactics that minimize reliance on insecticide use. Our results suggest that a combination of action thresholds for timing insecticide sprays and an onion cultivar that resists thrips damage is a step forward in this direction. More research is needed to develop onion cultivars with high levels of resistance to T. tabaci, especially those that mature $\leq 120 \mathrm{~d}$ after planting, which will fit best into the Great Lakes production region. Cultural and biological control approaches that are practical, economical, and compatible with judicious insecticide use and host plant resistance also need further attention.

\section{Acknowledgments}

The assistance of many research assistants who painstakingly counted thrips for this project was greatly appreciated: A. Leach, E. Maloney, A. Ritter, and E. Smith. A great deal of thanks to M. Mortellaro for allowing this research to be conducted on Mortellaro Farms. This study was funded in part by the New York State Onion Research and Development Program.

\section{References Cited}

Boateng, C. O., H. F. Schwartz, M. J. Havey, and K. Otto. 2014. Evaluation of onion genotypes for resistance to Iris Yellow Spot (Iris yellow spot virus) and onion thrips, Thrips tabaci. Southwest. Entomol. 39: 237-260. 
Byrne, A. M., and Z. Szendrei. 2013. Onion thrips control, 2012. Arthropod Manage. Tests 38: E34.

Cramer, C. S., N. Singh, and N. Kamal. 2014. Screening onion plant introduction accessions for tolerance to onion thrips and iris yellow spot. HortScience 49: 1253-1261.

Damon, S. J., R. L. Groves, and M. J. Havey. 2014. Variation in epicuticular waxes on onion foliage and impacts on numbers of onion thrips. J. Am. Soc. Hort. Sci. 139: 495-501.

Diaz-Montano, J., M. Fuchs, B. A. Nault, and A. M. Shelton. 2010. Evaluation of onion cultivars for resistance to onion thrips (Thysanoptera: Thripidae) and Iris yellow spot virus. J. Econ. Entomol. 103: 925-937.

Diaz-Montano, J., M. Fuchs, B. A. Nault, J. Fail, and A. M. Shelton. 2011. Onion thrips (Thysanoptera: Thripidae): A global pest of increasing concern in onion. J. Econ. Entomol. 104: 1-13.

Diaz-Montano, J., J. Fail, M. Deutschlander, B. A. Nault, and A. M. Shelton. 2012. Characterization of resistance, evaluation of the attractiveness of plant odors, and effect of leaf color on different onion cultivars to onion thrips (Thysanoptera: Thripidae). J. Econ. Entomol. 105: 632-641.

Dutta, B., A. K. Barman, R. Srinivasan, U. Avci, D. E. Ullman, D. B. Langston, and R. D. Gitaitis. 2014. Transmission of Pantoea ananatis and P. agglomerans, causal agents of center rot of onion (Allium cepa L.), by onion thrips (Thrips tabaci) through feces. Phytopathology 104: 812-819.

Fournier, F., G. Boivin, and R. Stewart. 1995. Effect of Thrips tabaci (Thysanoptera: Thripidae) on yellow onion yields and economic thresholds for its management. J. Econ. Entomol. 88: 1401-1407.

Gent, D. H., L. J. du Toit, S. F. Fichtner, S. K. Mohan, H. R. Pappu, and H. F. Schwartz. 2006. Iris yellow spot virus: An emerging threat to onion bulb and seed production. Plant Dis. 90: 1468-1480.

Gill, H. K., H. Garg, A. K. Gill, J. L. Gillett-Kaufman, and B. A. Nault. 2015. Onion thrips (Thysanoptera: Thripidae) biology, ecology, and management in onion production systems. J. Integ. Pest Manage. 6: 6. (DOI: 10.1093/ jipm/pmv006).

Groves, R. L., S. Chapman, A. S. Huseth, C. L. Groves, and K. E. Frost. 2013. Evaluation of foliar insecticides for the control of onion thrips in dry-bulb onion, 2012. Arthropod Manage. Tests 38: E35.

Hoepting, C. 2015. Strategic management of onion thrips in onions, 2015. Cornell Cooperative Extension. Veg Edge 11: 4.

Hoffmann, M. P., C. H. Petzoldt, C. R. MacNeil, J. J. Mishanec, M. S. Orfanedes, and D. H. Young. 1995. Evaluation of an onion thrips pest management program for onions in New York. Agric. Ecosys. Environ. 55: 51-60.

Hsu, C., C. A. Hoepting, M. Fuchs, A. M. Shelton, and B. A. Nault. 2010. Temporal dynamics of Iris yellow spot virus and its vector, Thrips tabaci (Thysanoptera: Thripidae), in seeded and transplanted onion fields. Environ. Entomol. 39: 266-277.

McKenzie, C.L., B. Cartwright, M.E. Miller, and J. V. Edelson. 1993. Injury to onions by Thrips tabaci (Thysanoptera: Thripidae) and its role in the development of purple blotch. Environ. Entomol. 22: 1266-1277.

Nault, B. A., and M. L. Hessney. 2006. Onion thrips control in onion, 2005. Arthropod Manage. Tests 31: E39.

Nault, B. A., and M. L. Hessney. 2011. Onion thrips control in onion, 2010. Onion thrips control in onion - Trial I, 2010. Arthropod Manage. Tests 36: E51.

Nault, B. A., and A. M. Shelton. 2010. Impact of insecticide efficacy on developing action thresholds for pest management: A case study of onion thrips (Thysanoptera: Thripidae) on onion. J. Econ. Entomol. 103: 1315-1326.

Nault, B. A., C. Hsu, and C. Hoepting. 2013. Consequences of co-applying insecticides and fungicides for managing Thrips tabaci (Thysanoptera: Thripidae) on onion. Pest Manag. Sci. 69: 841-849.

Nault, B. A., A. S. Huseth, and E. A. Smith. 2014. Onion thrips control in onion, 2013. Arthropod Manage. Tests 39: E39.

Reitz, S. R. 2014. Onion thrips (Thysanoptera: Thripidae) and their management in the Treasure Valley of the Pacific Northwest. Fla. Entomol. 97: 349-354.

SAS Institute. 2012. SAS/STAT Version 9.4. SAS Institute, Cary, NC.

Shelton, A. M., B. A. Nault, J. Plate, and J.-Z. Zhao. 2003. Regional and temporal variation in susceptibility to lambda-cyhalothrin in onion thrips, Thrips tabaci (Thysanoptera: Thripidae), in onion fields in New York. J. Econ. Entomol. 96: 1843-1848.

Shelton, A. M., J. Z. Zhao, B. A. Nault, J. Plate, F. R. Musser, and E. Larentzaki. 2006. Patterns of insecticide resistance in onion thrips (Thysanoptera: Thripidae) in onion fields in New York. J. Econ. Entomol. 99: 1798-1804.

Werling, B., and Z. Szendrei. 2015. Recipe for a cost-effective onion thrips control program. Michigan State University Extension. (http://msue.anr. msu.edu/uploads/files/2015_Onion_thrips_control_factsheet.pdf) (accessed 15 May 2016). 